\title{
MAPPING JUNIOR HIGH SCHOOL STUDENTS' FUNCTIONAL LITERACY COMPETENCE
}

\author{
Burhan Nurgiyantoro*, Beniati Lestyarini, Dwi Hanti Rahayu \\ Universitas Negeri Yogyakarta, Indonesia \\ *e-mail: burhan@uny.ac.id
}

\begin{abstract}
Literacy issues have probably been a special concern of many countries. In Indonesia, there have also been several surveys regarding the literacy of school students. This study aims to map the functional literacy competence of junior high school (JHS) students by focusing on various types of literacy competence and how each of them contributes to the overall functional literacy competence. This quantitative survey research involved 246 junior high school students from four regencies and one municipality of the Special Region of Yogyakarta as its sample. The research instrument was an extension of the National Assessment for Adult Literacy (NAAL) with some additions of functional literacy types suggested in the focus group discussion. Data were collected by using a test and subsequently analyzed through descriptive statistics and confirmatory factor analysis using the structural equation model with Lisrel. The results revealed that the functional literacy of the JHS students was mostly in the "medium" (83.3\%), "low" (15.4\%), and "high" (1.2\%) category. Of the 15 types of literacy, two of them $(13.33 \%)$, namely prose and cultural literacy made "high" contribution to the functional literacy as a whole, and two others (document and environmental literacy) also supported to a "medium" extent (13.33\%), while the rest $(60 \%)$ were categorized as having "low" contribution that means cannot be retained as factors that give significant contribution to the functional literacy competence. This likely implies the importance of fostering various types of functional literacy at school for students to have the ability to develop their personal and social functions.
\end{abstract}

\section{Keywords: functional literacy, functional literacy mapping, types of literacy, junior high school student}

\section{PEMETAAN KEMAMPUAN LITERASI FUNGSIONAL SISWA SEKOLAH MENENGAH PERTAMA ${ }^{1}$}

\begin{abstract}
Abstrak: Dewasa ini masalah kompetensi literasi menjadi perhatian di banyak negara. Di Indonesia juga sudah ada sejumlah survei mengenai kompetensi literasi anak sekolah. Penelitian ini bertujuan untuk memetakan kompetensi literasi fungsional siswa SMP yang terdiri atas berbagai jenis literasi dan bagaimana sumbangan tiap jenis literasi itu terhadap kompetensi literasi fungsional secara keseluruhan. Penelitian ini merupakan penelitian survei secara kuantitatif. Subjek penelitian adalah siswa SMP di lima kabupaten/kota madya Daerah Istimewa Yogyakarta dengan jumlah sampel sebanyak 246 orang. Instrumen penelitian merupakan perluasan NAAL dengan tambahan jenis literasi fungsional hasil FGD. Teknik pengumpulan dilakukan lewat tes, sedang analisis data melalui statistik dekriptif dan confirmatory factor analysis dengan Sructural Equation Model dengan bantuan program Lisrel. Hasil penelitian menunjukkan bahwa kompetensi literasi fungsional siswa sebagian besar berada pada peringkat sedang $(83,3 \%)$, rendah $(15,4 \%)$, dan tinggi $(1,2 \%)$. Dari ke-15 jenis literasi yang tinggi sumbangannya terhadap kompetensi literasi fungsional secara keseluruhan (sebesar13,33\%) adalah literasi prosa dan budaya, berkategori sedang $(13,33 \%)$ literasi dokumen dan lingkungan, sedang jenis yang lain berkategori rendah yang artinya tidak dapat dipertahankan sebagai faktor yang memberikan kontribusi signifikan terhadap kompetensi literasi fungsional siswa. Hal itu menyiratkan pentingnya pembinaan berbagai jenis literasi fungsional di sekolah agar para siswa memiliki kemampuan untuk mengembangkan diri pribadi dan fungsi sosial kemasyarakatan.
\end{abstract}

Kata Kunci: literasi fungsional, pemetaan kompetensi literasi fungsional, jenis literasi, siswa SMP

${ }^{1}$ This is a continuation of previous year's research paper published in Litera. Burhan Nurgiyantoro, Beniati Lestyarini, \& Dwi Hanti Rahayu. (2020). Konstruk assesmen literasi fungsional untuk siswa sekolah menengah pertama. Litera, Jurnal Penelitian, Bahasa, Sastra, dan Pengajarannya, 19(2), 194-211. https://journal.uny.ac.id/index.php/litera/article/view/32977. 


\section{INTRODUCTION}

Currently, literacy issues have been researchers' special interest in many countries. For example, over the last two decades, there have been a large number of nationwide surveys, such as in England (Department for Business, Innovation, and Skills, 2012); Germany (Grotlüschen, Riekmann, Buddeberg, 2014; Mallows \& Litster, 2016) as well as in a global scope (Kirsch, Yamamoto, Norris, Rock, Jungeblut, O'Reilly, ... \& Baldi, 2001; OECD, 2013,2018 ) that have identified that a vast proportion of the working-age population has low levels of literacy skills. This phenomenon encourages joint efforts by governments in many of these countries to improve the literacy skills of their people through the development of literacy programs to support life. Efforts to increase such skills aim to encompass functional literacy. This is due to the fact that such literacy competencies will concretely affect the achievement of the community conditions that are also functional (Cocchiarella, 2018).

In its development, the required skills cover various fields, such as digital literacy, technology, finance, transportation, culture, and others. Changes in the concept of literacy were initiated by the New London Group $(2005 ; 1996)$ with the concept of multiliteration associated with multiple intelligence possessed by humans so that it creates more demands for literacy competencies. Literacy is conceptualized as a social activity preconditioned within the scope, and aims at social-community, knowledge in social relations that is not in a neutral state (Fraire, 2005). The initial concept of literacy as merely reading and writing skills is no longer considered sufficient to respond to digital age demands and community needs.

As indicated above, some research includes several domains of literacy to investigate. There are three types of functional literacy competencies measured in the National Assessment of Literacy Survey (NALS), namely prose, document, and quantitative literacy (Hauser, 2005). NALS was then revised to be the National Assessment for Adult Literacy (NAAL) providing a more complete description of the levels of performance of functional literacy skills while remaining based on prose, document, and quantitative literacy.

Several instruments have been developed in Indonesia to measure students' literacy competence, for example, the Indonesian Student Competency Assessment (AKSI) or the Indonesia National Assessment Program (INAP) which can provide an overview of student literacy (Solihin, Utama, Pratiwi, \& Novirina, 2019). Whilst at worldwide level there are instruments known as ALI (The Assessment Literacy Inventory) and NALS which was later developed into NAAL. The latter focuses on three literacy competencies, namely prose, document, and quantitative literacy (Hauser, 2005). Similar to this, IEA Reading Literacy Studies emphasizes three types of texts, namely narrative prose, expository prose, and documents (Park, 2008). The same idea is seen in the International Adults Literacy Survey (IALS) which also emphasizes three types of literacy, namely prose, document, and quantitative literacy (Park, 2008).

Besides, the United Nations has designated year 2015 as the "UN Literacy Decade" which implies that in that year all citizens of the world must be free from illiteracy (Janjic-Watrich, 2009: 559). Therefore, various UN's literacy programs are mandated to various countries in the world to be practically enforced in eradicating illiteracy and developing functional literacy for a better life. Concerning this, the School Literacy Movement (SLM) launched by the Government of Indonesia via the Ministry of Education and Culture (starting in 2015) is an application of this UN policy.

One of the achievements of students in terms of literacy can be seen from the data of the Program for International Student Assessment (PISA). PISA assessment questions are dominated with higher-order thinking skills in the form of interpretation, reflection, and evaluation skills. However, the results of this survey showed that Indonesian students always had low performance as seen in 2012, 2015, and 2018 PISA results (OECD, 2013, 2018, 2019; Harsiati, 2018; Suryaman, 2015). This indicates that Indonesia still needs to strive to encourage students and citizens to advance with a variety of functional literacy competences.

The importance of literacy skills has been demonstrated in many studies. Examples of this include the mastery of functional literacy skills and their relationship with the ability to access and utilize digital libraries (Olaniran, 2020; Handley, 2018; Bohannon, 2015), learning to 
write (Sheperd \& Goggin, 2012), and reading comprehension (Dolenc, Aberšek, \& Aberšek (2015). Research studies by Mallows \& Litster (2016) and Rabušicová \& Oplatková (2010) reveal that people with low functional literacy competencies are likely to have a low chance of getting the desired job. Numerous literacy surveys both at the national and international levels above, among others, are intended to measure students' skills to actively reflect on their knowledge and experience, as well as skills to overcome various confronted problems.

The above studies indicate the importance of investigating the functional literacy competence of students in Indonesia, especially at the junior and senior high school level, as part of the efforts to support the National Literacy Movement (NLM) and the School Literacy Movement (SLM) currently being intensely promoted by the Indonesian government. As functional literacy has various types and not all of them have been studied for their role, effectiveness, or even mapping, this study comprehensively investigates types of functional literacy, namely 15 types of functional literacy developed through the authors' previous study, including those related to students' daily needs. However, this research is deliberately limited to JHS students, while similar investigation involving high school students are expected to be carried out in the next research.

Considering the above description, this study aims to map the functional literacy competence of JHS students, by taking in various types of literacy and how each of them contributes to the overall functional literacy. The mapping results obtained can be used for various purposes, but the main one is - in addition to supporting NLM and SLM - providing suggestions for improving the learning of certain types of functional literacy skills that are still less mastered by students at school.

\section{METHOD}

This quantitative survey research (Creswell, 2017) set out to measure and map junior high school students' functional literacy competence. The research subjects were JHS students in four regencies and one municipality in the Special Region of Yogyakarta, with one participating school for each regency/ municipality. The sample members were purposively selected for facilitating data collection as the involved teachers for the focus group discussion (FGD) were the heads of the teacher associations (MGMP). The contributing students, likewise, were selected randomly from grade 7 . The school selected in each area and the number of its students participating in this study are presented in Table 1.

Table 1. Selected JHSs and Number of Students per Regency/Municipality

\begin{tabular}{cllc}
\hline No. $\begin{array}{l}\text { Regency/ } \\
\text { Municipality }\end{array}$ & $\begin{array}{l}\text { Junior High } \\
\text { School }\end{array}$ & Total \\
\hline 1. Yogyakarta & JHS Kotamadya & 48 \\
2. Bantul & JHS Bantul & 50 \\
3. Kulon Progo & JHS Kulon Progo & 50 \\
4. Gunungkidul & JHS Gunungkidul & 49 \\
5. Sleman & JHS Sleman & 49 \\
\hline \multicolumn{2}{l}{ Total participating students in Yogyakarta } & 246 \\
\hline
\end{tabular}

The data collection instrument used was a previously developed assessment instrument. It was is a combination of the NAAL (National Assessment for Adult Literacy) components added with some FGD points suggested by experts and stakeholders (JHS teachers). The addition of functional literacy types is based on the consideration that the suggested types of literacy are very much needed in life and therefore are functional. Based on the FGD, 15 types of functional literacy needed in students' daily lives both at school and in the community were included to be measured. The 15 types of functional literacy are prose, digital, document, numerical, environmental, health, tourism, transportation, road safety, linguistic politeness, disaster mitigation, financial, cultural, visual, and social literacy. The test grid for the 15 types of functional literacy is shown in Table 2.

In item analysis, the Rasch model has been widely used. This model has been developed with various options as needed, for example, the Partial Credit Model (PCM), the Graded Partial Credit Model (GPCM), and the Rating Scale Model/Rating Model (RSM/RM) (Ostini \& Nering, 2006). In this study, the Rasch Model was employed with the help of the QUEST program to see the probability level, reliability index, MNSQ INFIT, and delta/threshold values. The reliability value based on the estimated item (Wright \& Master, 1982) is called the sample reliability. The INFIT MNSQ value based on 
the Rasch model is $.77-1.30$. The level of difficulty of each item can be seen based on the item estimates (thresholds) which indicate the item difficulty index. The level of difficulty of the thresholds is in the range $\pm 2(-2.00-2.00)$, which means that all items are acceptable.

Table 2. The Blueprint of the Functional Literacy Assessment Instrument

\begin{tabular}{clcc}
\hline No. & $\begin{array}{l}\text { Types of Functional } \\
\text { Literacy }\end{array}$ & $\begin{array}{c}\text { Total } \\
\text { Item }\end{array}$ & Item Number \\
\hline 1. & Prose & 4 & $1,16,31,46$ \\
2. & Digital & 4 & $2,17,32,47$ \\
3. & Document & 4 & $3,18,33,48$ \\
4. & Numerical & 4 & $4,19,34,49$ \\
5. & Environmental & 4 & $5,20,35,50$ \\
6. & Health & 4 & $6,21,36,51$ \\
7. & Tourism & 4 & $7,22,37,52$ \\
8. & Transportation & 4 & $8,23,38,53$ \\
9. & Road safety & 4 & $9,24,39,54$ \\
10. & Linguistic politeness & 4 & $10,25,40,55$ \\
11. Disaster mitigation & 4 & $11,26,41,56$ \\
12. & Financial & 4 & $12,27,42,57$ \\
13. & Cultural & 4 & $13,28,43,58$ \\
14. & Visual & 4 & $14,29,44,59$ \\
15. & Social & 4 & $15,30,45,60$ \\
\hline
\end{tabular}

The original grid has a competency indicator column which can be seen in Litera (https://journal.uny.ac.id/index.php/ litera/article/view/32977).
Data were collected using a test administered to all JHS student respondents. The data were then analyzed through descriptive statistics and the use of criteria table showing the three score categories, namely high, medium, and low (see Table 3; modified from Azwar, 2012) with the help of SPSS version 25. Besides, confirmatory factor analysis with Lisrel was conducted to examine the contribution of each type of literacy to functional literacy as a whole (Ghozali, 2017).

Table 3. JHS Students' Functional Literacy Criteria

\begin{tabular}{|c|c|c|}
\hline No. Interval Score & Rank & Category \\
\hline 1. $\bar{X}+1 s \leq X$ & 3 & High \\
\hline 2. $\bar{X}-1 s \leq X<\bar{X}+1 s$ & 2 & Medium \\
\hline 3. $X<\bar{X}-1 s$ & 1 & Low \\
\hline
\end{tabular}

RESULTS AND DISCUSSION

Results

The Functional Literacy Competency Assessment Results

Descriptive data on the results of the functional literacy assessment on JHS students per regency/municipality and its total number in the Special Region of Yogyakarta are presented in Table 4. Based on these data, further calculations were carried out to produce a mapping of students' functional literacy competencies.

Table 4. Descriptive Statistics Data on the Functional Literacy Competency Assessment of JHS Students in Yogyakarta's Regencies and Municipality

\begin{tabular}{lcccccc}
\hline \multirow{2}{*}{ Junior High School } & \multicolumn{6}{c}{ Descriptive Statistics } \\
\cline { 2 - 7 } & $\boldsymbol{N}$ & Minimum & Maximum & Sum & Mean & Std. Deviation \\
\hline JHS Kotamadya & 48 & 23 & 50 & 1.925 & 40.10 & 6.213 \\
JHS Bantul & 50 & 25 & 49 & 2.038 & 40.76 & 5.546 \\
JHS Kulon Progo & 50 & 24 & 48 & 2.039 & 40.78 & 4.888 \\
JHS Gunungkidul & 49 & 23 & 50 & 2.020 & 41.22 & 5.509 \\
JHS Sleman & 49 & 21 & 53 & 2.094 & 42.73 & 5.267 \\
Valid $N$ (listwise) & 48 & & & & & \\
\hline JHS DIY & 246 & 21 & 53 & 10.116 & 41.12 & 5.522 \\
\hline
\end{tabular}

\section{JHS Students' Functional Literacy Competency Mapping Results}

With a mean of 41.12 and a standard deviation of 5.52 and referring to the criteria as shown in Table 3, students' assessment scores can be mapped into three categories of functional literacy, namely high, medium, and low as a conversion guide. After being calculated based on this conversion guideline, the frequency and percentage of students in each functional literacy category can be seen in Table 5 . 
Table 5. JHS Students' Functional Literacy Competency Mapping Results

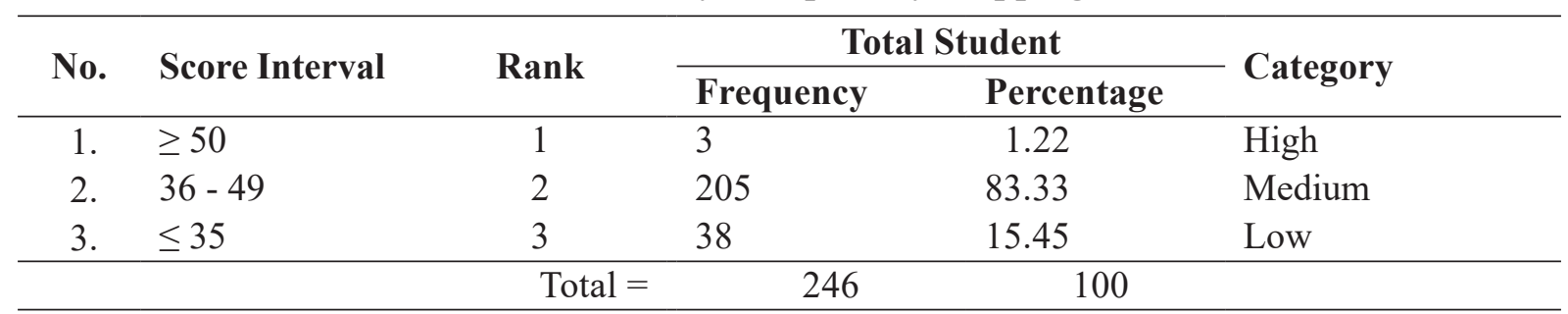

In the Table 5, the results of the mapping of functional literacy competencies for JHS students in the Special Region of Yogyakarta can be clearly seen. The mapping results indicate that most JHS students in the researched areas are in the "medium" category. The rest is in the "low" category and a small portion is in the "high" category.
The 15 Types of Functional Literacy Competency Assessment Results

The results of the functional literacy competence assessment which consists of 15 functional literacy types are presented in Table 6.

Table 6. Descriptive Data on the 15 Types of Functional Literacy Competency Assessment Results

\begin{tabular}{|c|c|c|c|c|c|c|c|}
\hline \multirow{2}{*}{ Type } & \multicolumn{7}{|c|}{ Descriptive Statistics } \\
\hline & $N$ & Range & Minimum & Maximum & Sum & Mean & Std. Deviation \\
\hline Prose & 246 & 3.00 & .00 & 3.00 & 392.00 & 1.5935 & .70955 \\
\hline Digital & 246 & 4.00 & .00 & 4.00 & 401.00 & 1.6301 & .66190 \\
\hline Document & 246 & 4.00 & .00 & 4.00 & 496.00 & 2.0163 & .82792 \\
\hline Numerical & 246 & 4.00 & .00 & 4.00 & 694.00 & 2.8211 & .90831 \\
\hline Environmental & 246 & 4.00 & .00 & 4.00 & 701.00 & 2.8496 & .83650 \\
\hline Health & 246 & 4.00 & .00 & 4.00 & 684.00 & 2.7805 & .89019 \\
\hline Tourism & 246 & 4.00 & .00 & 4.00 & 756.00 & 3.0732 & .84439 \\
\hline Transportation & 246 & 4.00 & .00 & 4.00 & 740.00 & 3.0081 & .96465 \\
\hline Road safety & 246 & 4.00 & .00 & 4.00 & 680.00 & 2.7642 & 97797 \\
\hline Linguistic politeness & 246 & 4.00 & .00 & 4.00 & 703.00 & 2.8577 & .93026 \\
\hline Disaster mitigation & 246 & 4.00 & .00 & 4.00 & 705.00 & 2.8659 & .89117 \\
\hline Financial & 246 & 4.00 & .00 & 4.00 & 641.00 & 2.6057 & 95779 \\
\hline Cultural & 246 & 4.00 & .00 & 4.00 & 626.00 & 2.5447 & .90578 \\
\hline Visual & 246 & 4.00 & .00 & 4.00 & 549.00 & 2.2317 & 1.00162 \\
\hline Social & 246 & 4.00 & .00 & 4.00 & 569.00 & 2.3130 & .99159 \\
\hline $\begin{array}{ll}\text { Valid } N(\text { list wise }) & = \\
\text { Mean Total } & = \\
\text { Std. Deviation } & =\end{array}$ & $\begin{array}{l}6 \\
2.467 \\
494\end{array}$ & & & & & & \\
\hline
\end{tabular}

The Contribution of Functional Literacy Types to the Overall Functional Literacy Competence

The relationship and contribution of the 15 types of functional literacy to students' functional literacy competencies can be seen through the results of the confirmatory factor analysis depicted in the output path diagram in the SEM program. The calculation results referred to are shown in Figure 1.

The analysis results show that the ChiSquare value ( $p$ value) is .000 and the RMSEA
$=.056(.08)$. To see if the model fits empirical data or called "model fit", several model fit criteria are proposed. The model is considered fit if it has a significance value $(p)$, the CFI value .77 (.09), and RMSEA <.08. Dimension and loading factor indicators of lambda $\lambda$ are in the model. Besides, the significance level should be $5 \%$ with a critical value of $t=1.98$.

In the CFA structural equation model above, the covariance relationship between variables, factors, and indicators is observable. 
The model created is in accordance with the empirical data obtained from the assessment results. The structural model analysis shows the loading factor component or latent variable indicated by the lambda value. From Figure
1 , the results of the structural loading factor recapitulation for the contribution of the 15 types of functional literacy to the overall functional literacy competency can be thoroughly presented.

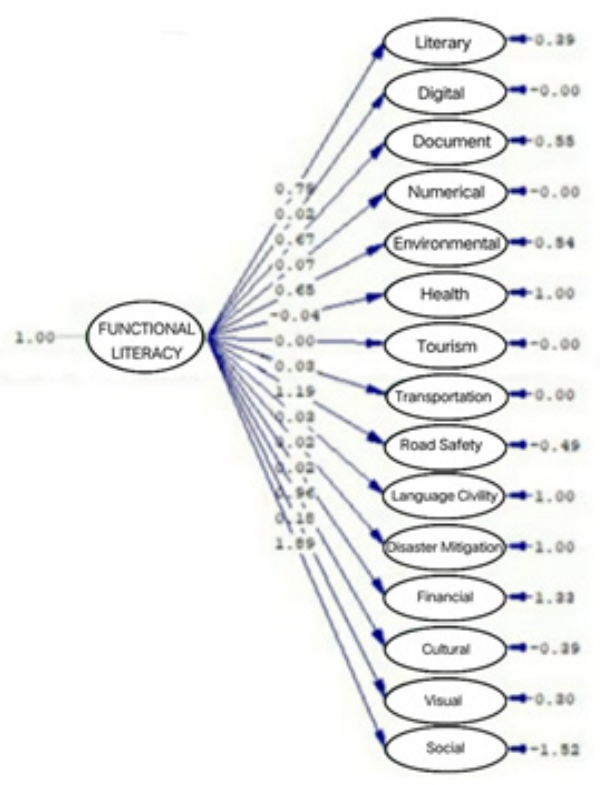

Figure 1. The Contribution of Functional Literacy Types to the Overall Functional Literacy Competence

The recapitulation results are then divided into three categories, namely high, medium, and low. The criteria used are as follows: $\geq .76$ means "high"; $.3-.75$ is "medium"; and $<.3$ is "low". If these criteria are used to classify the results of the loading factor of the 15 types of functional literacy as shown in Figure 1, the extent to which the 15 types of functional literacy contribute to the sought functional literacy competence is shown in Table 7.

Table 7. The Contribution of the 15 Types of Functional Literacy to the Overall Functional Literacy Competence Level

\begin{tabular}{rlcll}
\hline No. & $\begin{array}{l}\text { Components of } \\
\text { Functional Literacy }\end{array}$ & $\begin{array}{l}\text { Loading } \\
\text { Factor }\end{array}$ & Category & Remark \\
\hline 1. & Prose & .79 & High & 1) High $=2(13.33 \%)$ \\
2. & Digital & .02 & Low & 2) Medium $=2(13.33 \%)$ \\
3. & Document & .67 & Medium & 3) Low $=9(60 \%)$ \\
4. & Numerical & .07 & Low & 4) Not convergent = 2 (13.33\%) \\
5. & Environmental & .65 & Medium & \\
6. & Health & .04 & Low & \\
7. & Tourism & .00 & Low & \\
8. & Transportation & .03 & Low & \\
9. & Road safety & 1.19 & Not convergent & \\
10. & Linguistic politeness & .03 & Low & \\
11. & Disaster mitigation & .02 & Low & \\
12. & Financial & .02 & Low & \\
13. & Cultural & .96 & High & \\
14. & Visual & .18 & Low & \\
15. & Social & 1.89 & Not convergent & \\
\hline
\end{tabular}


The result shows that only four types of functional literacy (prose, document, environmental, cultural) have factor loading values that can be retained as contributor for its holistic competence $(26.66 \%)$ with the values in between $.3-1.00$. While other categories (low and not convergent) cannot be retained as factors that significantly contribute to the functional literacy competence. These give an impact to the reevalution of the determination of the factors, numbers of factors and other context that influence the test and student's achievement.

\section{Discussion}

\section{Students' Functional Literacy Competence}

Functional literacy competence can be considered as a reflection of a person's ability in carrying out various functions of social life in society, as well as undergoing, dealing with, and solving various problems encountered in everyday life. This competence requires a person to be able to interpret an object in the form of either writing products, visual manifestations, or actions not only from what is expressed, but also what is implied. Functional literacy competence demands these things as it is required to appropriately understand the "rules" of people's sociocultural life.

On the other hand, a person can be said to be incapable to adapt to the sociocultural environment and its physical environment if he/she fails to be functionally literate in those domains. This is due to the fact that "we need functional literacy to have a functional society (Cocchiarella, 2018)." Thus, the existence of conditions for functional literacy competence from various domains is a prerequisite for achieving a functional condition of society. The field of evaluation and assessment answers how to see this competence since assessment becomes "... many techniques that we have use to measure and judge students' behavior and performance" (van Blerkom, 2009: 6).

Based on the results of the mapping, of the 15 types of functional literacy competences of the JHS students, a large proportion (83.33\%) is at the "medium" level, while those at the "low" category are relatively a lot (15.45\%), and those at "high" category are very small in number $(1.22 \%)$. In general, it shows that the functional literacy competence of these students seems not sufficient for their lives and thus still requires support from various lessons and experiences to reach a higher level. If someone who masters the literacy competence is called a literate person, it means that these students have not reached the status of literate humans yet. As the goal of achieving a functional society requires functional literacy competence (Cocchiarella, 2018), it can be understood that the literacy competence of JHS students is insufficient to achieve that goal.

The results of the functional literacy competence mapping of JHS students are in line with, or even strengthen by, the results of a survey conducted by the OECD in the form of PISA (Program for International Student Assessment) test, for example, PISA in the last three years, namely 2012, 2015, 2018. PISA survey results covering three types of literacy in mathematics, science, and reading show that Indonesian JHS students stay at a low level (OECD, 2013, 2018, 2019). The rankings have changed slightly, and even have increased, but in overall terms of the number of countries taking part, the achievements of Indonesian students are still in the low range.

If traced to a lower level of education, namely the elementary school level which also has an international survey called PIRLS (Progress in International Reading Literacy Study (for grade 4 students), the results of the literacy competency survey for Indonesian children reveal no difference (Mullis, Martin, Foy, \& Drucker, 2012; Mullis, Martin, Foy, \& Hooper, 2018). This means that the results of the international survey for Indonesian younger students are equally low. This also shows that there is a parallel result among PIRLS, PISA. And the mapping of functional literacy competence under this study. Moreover, in this PIRLS survey, the literacy competence tested was only one type, namely reading. The reading test itself was then divided into two groups of reading genres, namely literary and information reading (Musfiroh \& Lestyorini, 2016).

The literacy survey at the primary and secondary school level conducted by Laksono \& Retnaningdyah (2018) to see the implementation of the Regulation of the Ministry of Education No. 24 of 2007 on the availability of school libraries as the main support for the implementation of the SLM was carried out in East Java. The 
study found that many schools did not meet the required standards such as having a low standard of facilities as the number of schools that have a standardized number of books for knowledge enrichment is only about 5\% (Laksono \& Retnaningdyah, 2018). Besides, they add, students from poor families have more limited access to public libraries or bookstores. This seems to contradict the fact that the existence of libraries with an adequate number and types of reading books becomes the key to the success of SLM. The research, therefore, directly or indirectly support this survey.

The results of this mapping support the survey on the National Alibaca Index or the Reading Literacy Competency Index. The results of the National Alibaca Index survey's mean value is in a low category, which is 37.32 (Solihin et al., 2019). This index depicts four types of indicators or dimensions, namely the proficiency dimension index (a mean of 75.92), the access dimension index (23.09), the alternative dimension index (40.49), and the cultural dimension index (28.50) (Solihin et al., 2019). The value of each dimension is an aggregate of several indicators. The survey also shows that the index of the dimensions of access and culture is the lowest contributor to the final value of the National Alibaca Index, while the other two dimensions appear to have a greater contribution rate even though not relatively high either. The two-dimensional indexes that are still low likely require more intensive attention and handling.

This mapping involved JHS students as the subjects who can be considered as children or, to be precise, teenagers. If their functional literacy competence is compared with that of adults in various countries in the world, the conclusion would also be the same as the previous. For example, a survey conducted in Germany shows that there are still $25 \%$ of the adult population with low functional literacy competencies (Grotlüschen, Mallows, Reder, \& Sabatini, 2016). This condition seems to be similar to that of other countries, for example, Italy $27.7 \%$, Spain 27.5\%, France 21.6\%, and Poland 18.8\%. For countries such as Finland (10.6\%), Slovak Republic (11.6\%), the Netherlands (11.7\%), and Czech Republic (11.8\%), the survey results on literacy competence are perceived better
(Grotlüschen et al., 2016; Mallows \& Litster, 2016).

Literacy competence surveys in these countries fall into two categories. First, the population that is deemed to have no social function is rooted in low, or even lacked functional literacy competencies and is known as those with a literary crisis. Second, the population is categorized as a functionally illiterate population with implications for economic consequences is also seen as the impact of poor literacy (Grotlüschen et al., 2016; Mallows \& Litster, 2016). This shows that in various countries, citizens with low functional literacy competence will find it difficult to compete in the world of work. All of this will have an impact on the economic sphere and in turn, lead to lower social functions.

Various related surveys in different countries show that there is a serious impact of inadequate functional literacy competence, especially in the economic sector. The condition of the community supported by its members with difficulties in this aspect will certainly experience troubles in progressing and developing, problems in accessing and obtaining a decent job, in being able to live properly as everything is completely limited, and so on. In essence, the condition of community members with low functional literacy competence will affect the community state to arrive at predetermined functional community goals.

However, because this survey was conducted on students who were still adolescents, there seem to be many opportunities to overcome this low functional literacy competency for their future being. In many ways, literacy is the competency and practical skills needed in social life and plays a role in social life (Cocchiarella, 2018), so matters related to the various types of literacy needs above would necessitate thoughtful attention at school. In fact, there are many types of functional literacy, but the first and foremost aspect that forms the basis for the achievement of these competencies is reading competence. Therefore, the most principal thing that must be addressed is learning to read. Unfortunately, the national survey on the Alibaca index shows unexpected results. This, hence, should be one of the driving motivations to further intensify the learning of reading in schools. 


\section{The Contribution of Various Types of Literacy to Functional Literacy Competence as a Whole}

There are variations in the contribution of each type of literacy from the mapping results to the overall functional literacy competence. However, it can be briefly stated that the results of the mapping are only four types of literacy that can be considered as highly contributing, namely prose and culture (13.33\%) in "high" category, and two others, documents and the environmental literacy $(13.33 \%)$ in "medium" category, while the rest are in the "low" category that means not valid to give contribution to the overall achievement of functional literacy comptence. This condition can be understood with simple logic. Since most $(83.33 \%)$ functional literacy competencies are only in the "medium" and "low" category, the contribution of each type of literacy is of course not high. Thus, the finding suggests that there are only four types of literacy that provide good contributions, and this is in line with the results of the mapping of functional literacy competencies which is also not high. The extent of the contribution is determined by the score for each type of functional literacy.

Literacy, which was initially only interpreted as the ability to read and write, was initially intended to differentiate between literate and illiterate people, in its development, the meaning is now aligned with the terms 'knowledge' and 'skills' in various fields of life (Solihin et al., 2019). This means that now to master literacy competencies, people must also master the knowledge, adeptness, and skills in these various literacy fields. This is because various types of literacy show a connection among themselves. Mastery and/or proficiency in a functional literacy domain will affect the mastery, proficiency, and skills in other literacy fields, especially reading.

Concerning this, the current research shows that prose and cultural literacy types provide the greatest contribution to the overall functional literacy competency as both literacy domains are closely related. The prose, in this context, is limited to fictional prose as one of the genres of literary works, while in many ways literature is seen as a thick cultural manifestation. Hence, the two seem closely related. The keyword for literacy competence is reading competence. By reading a lot of literary works, students' imaginations will grow, and this may have a significant impact on improving their reading competence. Therefore, it seems not overstating if Pelettari (2016) proposes that the competence of imagining both concretely and abstractly is also learned as part of the literary learning method. All great works start from imagination, or all masterpieces require imagination to organize.

However, reading culture, or in this context willingness to read, may not grow by itself without the conscious effort of schools. Many factors influence the success of this business, including the availability of reading materials and willingness to read - which in the research of Solihin et al. (2019) above are referred to as the dimensions of access and culture as part of the four dimensions studied. The implementation of SLM, which requires students to read regularly, in terms of both days and duration of learning hours at school, seems to have an effect on functional literacy competence in this field. Therefore, the development of reading habits should be carried out at school.

Reading habit says to open "doors of knowledge" to readers as well as improve functional literacy competences. This seems to be able to explain why document and environmental literacy also make a relatively good contribution to the overall functional literacy competence. Various studies show that both competences affect various competencies in reading comprehension (Dolenc et al., 2015), in learning to write (Sheperd \& Goggin, 2012), even in accessing and utilizing digital libraries (Olaniran, 2020). Therefore, there seems to be an interplay among the various types of functional literacy competences.

On the other hand, the results of this study indicate that students' digital literacy competence is still low (loading factor .02) and therefore has little effect on the overall functional literacy competence. In fact, in today's digital era, digital literacy is a requirement for entering all spheres of science (Olaniran, 2020). Multiliteration competition that departs from the fact that the massive digital content must be addressed by increasing the digital competence or multiliterative competence of students. Likewise, other types of functional literacy have low achievements, such as health (.04), tourism (.00), transportation (.03), linguistic politeness (.03), disaster mitigation (.02), finance (.02), and 
visual (.018). These types of literacy should get more attention in terms of their development.

The indicators (and also questions or items) developed in this survey do not require cognitive thinking skills but are more related to the need to choose and behave in meeting the needs of daily life. In essence, the questions are more of a practical need, for example choosing the most appropriate (which is also socially prevalent) things to do, a form of expression to say, a plan of action to be carried out, behaving towards a situation, and so on. All of these are expected to form the personality of students who are increasingly literate to develop their potential and become helpful to others.

In the politeness question, by way of example, all of the answer choices provided are grammatically correct but different in terms of their politeness level. In actual linguistic phenomena, the social context should also receive attention. Seen from the perspective of pragmatic language politeness (Leech, 2014), the grammatically correct expression may be socially inappropriate perhaps because it feels rude, frontal, or less commonly used. This shows how important social "knowledge" is to interact in society.

To answer questions about different types of functional literacy, prerequisites required are to be able to read and understand the questions. Reading competence in terms of functional literacy is not only considered as a differentiator of literacy and illiteracy, but reading which requires certain skills, or what is called proficiency in the context of the Alibaca index (Solihin et al., 2019). Hence, when reading, students have to understand the explicitly and implicitly stated meaning, relate it to the real-life context, and associate it with various things outside the reading itself. In fact, students are also expected to understand various types of texts with various contents of meaning - for example digital issues, finance, tourism, transportation, mitigation, etc. - all of which are presented in various text genres according to literacy fields. In short, genre-based reading learning, reading texts from various genres, must be carried out more intensively.

For that matter, PIRLS and PISA questions also require student competence related to the above issues (OECD, 2013, 2018,
2019; Mullis et al., 2012; Mullis et al., 2018). However, like the results of this survey and the Alibaca index survey, the results of the PIRLS and PISA surveys of Indonesian children likely give low results consistently, even far below the world average. There might be a kind of belief that Indonesian students are not as stupid or that low as their competence in the various types of literacy they are tested on, but something has not been resolved so far. As an example, there might be something that the children feel unfamiliar with the form of the questions, so that they are just confused and not ready for them when suddenly asked to work on them. This condition becomes one of the challenges for advancing education in Indonesia.

\section{CONCLUSIONS}

The study would conclude that the functional literacy competence of most junior high school students in the Special Region of Yogyakarta is in the "medium" category $(83.3 \%)$, while the rest was categorized as low $(15.45 \%)$ and high (1.2\%). This shows that the functional literacy competence of students needs to be enhanced. They probably have not been able to apply their various competencies into choices, attitudes, and practical actions in accordance with the social context.

With regard to the contribution of 15 functional literacy types to the overall functional literacy competence, In general, these domains seem to have a little contribution. Of the 15 types of literacy that concretely contribute to the achievement of functional literacy competence as a whole, only four types make a significant number. They are prose and document literacy which are categorized as "high" (13.33\%), and document and environmental literacy types which are categorized as "medium" (13.33\%), while the rest is ("low" category) cannot be retained as significant factors that contribute to the achievement of student's functional literacy competence. This implies that schools should foster various types of functional literacy so that students can be literate human beings with the ability to develop personal and social functions. Genre-based reading learning should really be implemented to let the students familiar with texts from various genres. 


\section{REFERENCES}

Azwar, S. (2012). Reliabilitas dan validitas. [Reliability and validity]. Yogyakarta: Pustaka pelajar.

Bohannon, J. L. (2015). Not a stitch out of place: Assessing students' attitudes towards multimodal composition. Bellaterra Journal of Teaching Language \& Literature, 8(2), 33-47. https://doi. org/10.5565/rev/jt13.631.

Cocchiarella, C. (2018, 30 December). What is functional literacy, and why does our hightech society need it? Mindful Technics, a Technology Education Site and Blog for Geeks. https://mindfultechnics.com/whatis-functional-literacy/.

Creswell, J. W. (2017). Research design: Qualitative, quantitative, and mixed methods approaches ( $\left.{ }^{\text {th }} \mathrm{ed}\right)$. Los Angeles: SAGE Publications, Inc.

Department for Business, Innovation, and Skills. (2012). The 2011 skills for life survey: A survey of literacy, numeracy and ICT levels in England. London: Author.

Dolenc, K., Aberšek, B., \& Aberšek, M. K. (2015). Online functional literacy, intelligent tutoring systems and science education. Journal of Baltic Science Education, 14(2), 162-171. http://www. scientiasocialis.lt/jbse/?q=node $/ 421$.

Fraire, P. (2005). Education for critical consciousness. London: Continuum.

Ghozali, I. (2017). Structural equation model: Metode alternatif dengan Partal Least Squares (PLS). [Structural equation model: An alternative method with Partal Least Squares (PLS)]. Semarang: BP UNDIP.

Grotlüschen, A., Riekmann, W., \& Buddeberg, K. (2015). Stereotypes versus research results regarding functionally illiterate adults: Conclusions from the first German levelone survey and the learner panel study. In A. Grotlüschen \& D. Zimper (Eds.). Literalitäts- und Grundlagenforschung. Münster, Germany: Waxmann, pp. 105-
122.

Grotlüschen, A., Mallows, D., Reder, S., \& Sabatini, J. (2016). Adults with low proficiency in literacy or numeracy (OECD Education Working Papers, No. 131). Paris: OECD Publishing.

Handley, F. J. L. (2018). Developing digital skills and literacies in UK Higher Education: Recent developments and a case study of the digital literacies framework at the University of Brighton. Publicaciones, 48(1), 97-109. https://doi.org/10.30827/ publicaciones.v48i1.7327.

Harsiati, T. (2018). Karakteristik soal literasi membaca pada program PISA. [The characteristics of literacy test items in PISA]. Litera, Jurnal Penelitian Bahasa, Sastra, dan Pengajarannya, 17(1), 90-106. https://doi.org/10.21831/ltr. v17i1.19048.

Hauser, R. M. (2005). Measuring literacy: Performance level for adult. Washington, DC: The National Academies Press.

Janjic-Watrich, V. (2009). "The Cambridge handbook of literacy" by Olson, D. R. \& Torrance, R. Books Review. Alberta Journal of Educational Research, 55(Winter), 4. http://www.proquest/umi/ pqd.web.

Kirsch, I., Yamamoto, K., Norris, N., Rock, D., Jungeblut, A., O'Reilly, ... \& Baldi, S. (2001). Technical report and data file user's manual for the 1992 national adult literacy survey (NCES No. 2001-457.) Washington, DC: U.S. Department of Education, National Center for Education Statistics.

Laksono, K., \& Retnaningdyah, P. (2018). Literacy infrastructure, access to books, and the implementation of the school literacy movement in primary schools in Indonesia. IOP Publishing IOP Conf. Series: Materials Science and Engineering, 296 (2018) 012045, 1-9. https://doi.org/10.1088/1757899X/296/1/012045. 
Leech, G. N. (2014). The pragmatics of politeness. Oxford: Oxford University Press.

Mallows, D., \& Litster, J. (2016). Literacy as supply and demand. Zeitschrift für Weiterbildungsforschung, 39, 171-182. https://doi.org/10.1007/s40955-0160061-1.

Mullis, I. V. S., Martin, M. O., Foy, P., \& Drucker, K. T. (Eds.). (2012). PIRLS 2011 international results in reading. Chestnut Hill, MA: TIMSS \& PIRLS International Study Center, Boston College.

Mullis, I. V. S., Martin, M. O., Foy, P., \& Hooper, M. (2018). PIRLS 2016 International results in reading. Chestnut Hill, MA: TIMSS \& PIRLS International Study Center, Boston College.

Musfiroh, T. \& Listyorini, B. (2016). Konstruk kompetensi literasi untuk siswa sekolah dasar. [The constructs of literacy competence for elementary school students]. Litera, Jurnal Penelitian Bahasa, Sastra, dan Pengajarannya, 15(1), 1-12. https://doi.org/10.21831/ltr. v15i1.9751.

OECD. (2013). PISA 2012 Results: What students knows and can do - student performance Mathematics, Reading and Science (vol. I). Paris, France: Author.

OECD. (2018). PISA 2015 results in focus. Paris, France: Author.

OECD. (2019). PISA 2018 Results (vol. I): What students know and can do. Paris, France: Author. https://doi.org/10.1787/5f07c754en.

Olaniran, S. O. (2020). Literacy library and the functional literacy skills of the $21^{\text {st }}$ Century adult learners. Library Philosophy and Practice (e-journal), 3573, 1-12. https:// digitalcommons.unl.edu/libphilprac/3573.

Ostini, R., \& Nering, M. (2006). Polytomus item response theory models. New York, NY: SAGE Publication.

Park, Y. (2008). Patterns and predictors of elementary students' reading performance: Evidence from the data of the progress in International Reading Literacy Study (PIRLS). (Dissertation, Michigan State University). http://www.proquest/umi/ pqd.web.

Pelettari, C. (2016). Imagination and literacy instruction: A content analysis of literature within literacy-related publications. Language and Literacy, 18(3), 106-122. https://doi.org/10.20360/ G20027.

Rabušicová, M., \& Oplatková, P. (2010). Functional literacy in people's lives. Journal of Pedagogy, 1(2), 29-51. https:// doi.org/10.2478/v10159-010-0008-3.

Shepherd, R., \& Goggin, P. (2012). Reclaiming "old" literacies in the new literacy information age: The functional literacies of the mediated workstation. Composition Studies, 40(2), 66-91. https://www.jstor. org/stable/compstud.40.2.0066.

Solihin, L., Utama, B., Pratiwi, I., \& Novirina. (2019). Indeks aktivitas literasi membaca 34 provinsi. [Reading literacy activity index for 34 provinces]. Jakarta: Research Center for Education and Cultural Policy, Research and Development Agency, Ministry of Education and Culture.

Suryaman, M. (2015). Analisis hasil belajar peserta didik dalam literasi membaca melalui studi internasional (Pirls) 2011. [An analysis of students' learning outcomes of reading literacy through an international study (PIRLS) 2011]. Litera, Jurnal Penelitian Bahasa, Sastra, dan Pengajarannya, 14(1), 170-186. https:// doi.org/10.21831/ltr.v14i1.4416.

The New London Group. (2005). A pedagogy of multiliteracies: Designing social futures. In B. Cope \& M. Kalantziz (Eds). Multiliteracies: Literary learning and the design of social futures. South Yarra: Macmillan, pp. 9-38.

The New London Group. (1996). A pedagogy of multiliteracies: Designing social futures. Harvard Educational Review, 
66(1), 60-93. https://doi.org/10.17763/ haer.66.1.17370n67v22j160u.

van Blerkom, M. L. (2009). Measurement and statistics for teacher. Oxfordshire:

\section{Routledge.}

Wright, B. D., \& Master, G. N. (1982). Rating scale analysis. Chicago: Mesa Press. 